\title{
Experimental Trends in Corruption and Tax Evasion
}

\author{
Tendencias experimentales sobre corrupción \\ y evasión fiscal
}

\author{
Nuria Rodríguez-Priego \\ Ágnes Pintér \\ Universidad Autónoma de Madrid
}

\begin{abstract}
Nowadays, among the main social concerns of the Spanish society we find corruption and fraud, which occupy the second place in terms of relevance according to recent data. The traditional neoclassical economic approaches concentrate on the construction of economic models that aim to explain the causes of both social phenomena. However, in the last decade several studies have emerged focusing on a behavioral approach to improve the explanatory capacity of such models. In this sense, economic experiments have been implemented to examine, from a different perspective, the determinants of corruption, on the one hand, and fiscal fraud, on the other. Few empirical studies relate both social problems, especially when we refer to the tax evasion of individual economic agents. Therefore, this paper aims to review and deepen the understanding of the factors that determine and relate tax evasion and corruption, from an experimental approach.
\end{abstract}

Keywords: tax evasion, fraud, corruption, behavioral economics, economic experiments.

JEL Classification: $\mathrm{H} 2 \mathrm{O}, \mathrm{H} 26$.

\section{Resumen}

Entre las principales preocupaciones de la sociedad española, encontramos la corrupción y el fraude, que ocupan el segundo lugar en términos de relevancia según datos recientes. Los enfoques neoclásicos tradicionales se fundamentan en la construcción de modelos económicos que intentan explicar las causas de ambos fenómenos. Sin embargo, en la última década han surgido varios estudios centrados en un enfoque comportamental para mejorar la capacidad explicativa de dichos modelos. En este sentido, se han implementado experimentos económicos para estudiar, desde una perspectiva diferente, los determinantes de la corrupción, por un lado, y del fraude fiscal, por el otro. No obstante, pocos estudios empíricos relacionan ambos problemas sociales, especialmente cuando nos referimos a la evasión fiscal de agentes económicos individuales. Por ello, el objetivo de este artículo es revisar y profundizar en la comprensión de los factores que determinan y relacionan la evasión fiscal y la corrupción, desde el enfoque experimental.

Palabras clave: evasión fiscal, fraude, corrupción, economía del comportamiento, experimentos económicos.

Clasificación JEL: H20, H26. 


\section{Introduction}

Fraud and corruption are the second cause of concern among the citizens in the Spanish context, being only overcome by unemployment. These two problems have been escalating positions from 2011 to March 2013, when already $44.5 \%$ of Spaniards placed them among one of the three main concerns. The latest data indicates that $26.2 \%$ of the citizens are still worried about these two issues, keeping them on the second place in the last official barometer. ${ }^{1}$

Tax fraud is a reality of any society where there is a tax system. The submerged economy or shadow economy includes all economic activities that have not been officially accounted for -so they avoid administrative regulation- but would yield an increase in the Gross Domestic Product if they were registered (Feige, 1994; Dell'Anno \& Schneider, 2004; Schneider, 2015). Tax fraud is a detriment to public revenues, which reduces the available resources to be allocated on public services and infrastructure, such as education and health, among others, that in turn translates to lower living standards for the whole society. More specifically, tax evasion refers to illegal acts in which fiscal responsibility is hidden or ignored, either intentionally or due to ignorance or confusion. ${ }^{2}$ Regardless of intentionality, tax evasion is considered an illegal act and, consequently, is penalized by the government if detected.

Tax evasion was estimated at $€ 46$ billion in 2016 for the EU-28, which counts for $0.32 \%$ of the GDP, including three components of tax evasion: capital income, stock of wealth, and evasion on personal income tax. In Spain, the estimation counted for $€ 3.19$ billions. This is approximately $7 \%$ of the total estimated revenue loss in EU-28 and $0.3 \%$ of Spain's GDP (Vellutini et al., 2019).

On the other hand, although corruption and tax evasion are two separate social problems, tax contract theories raise the hypothesis that government performance can affect tax collection (Timmons \& Garfias, 2015). The data obtained in previous studies show that, when we refer to the decision to declare or evade taxes in the company environment, corruption and the possibilities of bribery of public authorities have a positive effect on the levels of tax evasion (Alm et al., 2016). As for other types of taxes, the evidence shows similar results. In the case of property taxes, the compliance levels decrease as the revealed corruption increases, and increase as audits reveal low (or zero) corruption levels (Timmons \& Garfias, 2015).

The concept of corruption is defined as the abuse of public power for private gain (Tanzi, 1998). For companies, the abuse of power could be suffered through the payment of bribes to start some type of business (Choi \& Thum, 2005), but other authors have indicated that such abuse could take place more generically. The

${ }^{1}$ Centro de Investigaciones Sociológicas (2019). Percepción de los principales problemas de España. http://www.cis.es/cis/opencms/ES/11_barometros/indicadores.html.

http://www.cis.es/cis/export/sites/default/-Archivos/Indicadores/documentos_html/TresProblemas.html.

2 OCDE. Glossary of Tax Terms (2019). Centre for Tax Policy and Administration. http://www.oecd.org/ ctp/glossaryoftaxterms.htm. 
literature has identified several aspects, such as the diversion of funds, excessive billing of goods and services, and irregularities in the contracting process, including fraud and contracts without tender (Timmons \& Garfias, 2015). Although the latter do not have a direct impact on the individual economic agent, it affects his perception of how the resources -collected through the payment of taxes- are used.

Corruption is considered a serious social threat in both developed and developing countries as it decreases productivity at the enterprise level due to inefficient assignments of contracts, distorts economic growth and reduces foreign investment (Habib \& Zurawicki, 2002; Aidt, 2011; Faruq et al., 2013). In addition, corruption reduces voluntary contributions to public goods and increases inequality (Beekman et al., 2014; Justesen \& Bjørnskov, 2014).

Despite the extensive literature on tax evasion and corruption, research that focuses on combining both problems and examining them from the point of view of behavioral economics is scarce. On the one hand, there are theoretical studies that relate corruption and evasion (Chander \& Wilde, 1992; Besley \& McLaren, 1993; Hindriks et al., 1999; Sanyal et al., 2000; Acconcia et al., 2003), but these studies are based on economic models that are not very flexible and do not consider the possibility of behavioral biases. On the other hand, as far as our knowledge goes, studies that adopt an experimental approach mainly focus on examining the relationship between corruption and tax evasion from the point of view of companies (Alm et al., 2016), or on the property tax (Timmons \& Garfias, 2015).

The objective of our paper is to resume and deepen the knowledge of the factors that determine tax evasion, on the one hand, and corruption, on the other, from the perspective of the experimental economy. To do this, we will take into account that individuals do not always follow the assumptions on which traditional theories are based, hence sometimes they do not behave in a purely selfish way, but rather care about concepts such as justice and fairness, social welfare, and others (Andreoni $\&$ Miller, 2002; Kahneman et al., 1986). This study would thus contribute to the empirical literature by providing information on the incentives that lead individuals to evade taxes, focusing specifically on the income tax of natural persons, since, as we have mentioned before, tax evasion related to individual economic agents is more difficult to detect by the administration. Moreover, we will explore the possible relationship between tax evasion and corruption, as separately both issues are widely studied, but few experimental studies tried to analyze both phenomena together.

\section{Tax evasion}

\subsection{From traditional to modern economic theories}

Tax fraud and tax evasion are terms used as synonymous. Both refer to the behavior of an economic agent who hides, disguises or manipulates his economic 
capacity by not paying the amount of taxes that he is obliged to pay according to the laws in force. On the other hand, tax avoidance is the behavior of taking advantage of a tax rule that was intended for a different purpose by the legislator, with the objective of paying fewer taxes. The importance of tax evasion lies in its relationship with public services, meaning that the more taxpayers evade, the less public services are provided. In addition, it also affects the precision of macroeconomic data and makes difficult to measure the real impact of taxation (Alm, 2012).

Traditional economic theory has tried to explain and measure tax evasion in the last decades. Allingham and Sandmo (1972) analyzed taxpayer's intentional decision to evade taxes, building their economic model on previous literature related with the economics of criminality from Becker (1968) and Tulkens and Jacquemin (1971), and the economics of uncertainty (Mossin, 1968). Their model is based on individual personal income and assumes that the taxpayer is risk averse. When deciding how much income to declare, the taxpayer can choose to declare his real income, or a lower quantity. In any case, the authorities may decide to investigate him. If the economic agent decides to evade, he will have to pay a penalty based on the quantity he has undeclared, plus the corresponding undeclared taxes. However, if the authorities do not audit him, he will be in a better situation compared to absolute tax compliance. The economic agent's decision responds to his expected utility maximization. The optimum is subject to the probability of being investigated, the size of the penalty, and the degree of risk aversion of the taxpayer. As a result, individuals pay taxes only if they think they will be caught and punished.

In this model, actual income is exogenously given and noted as $W$. This quantity is known by the taxpayer but not by the public authorities. The tax rate is set at $\theta$ on declared income, $X$. There is a probability of being audited $p$. Hence, the taxpayer pays $\theta \cdot X$, unless he is audited after deciding to underreport. In this case, he will have to pay the underreported quantity $W-X$ plus a penalty rate, $\pi(\pi>\theta)$. The taxpayer will choose $X$ so that he maximizes his expected utility:

$$
E[U]=(1-p) \cdot U(W-\theta \cdot X)+p \cdot U(W-\theta \cdot X-\pi(W-X))
$$

If we note:

$$
\begin{gathered}
Y=W-\theta \cdot X \\
Z=W-\theta \cdot X-\pi(W-X)
\end{gathered}
$$

The first order conditions equals $E^{\prime}[U]$ to zero:

$$
-\theta(1-p) \cdot U^{\prime}(Y)-(\theta-\pi) p \cdot U^{\prime}(Z)=0
$$


The second order condition

$$
D=\theta^{2}(1-p) U^{\prime \prime}(Y)+(\theta-\pi)^{2} p \cdot U^{\prime \prime}(Z)
$$

is negative because we assume concavity of the utility function.

If we set the expected utility at $X=0$ and $X=W$, we can evaluate whether it exists an interior solution. It would require that:

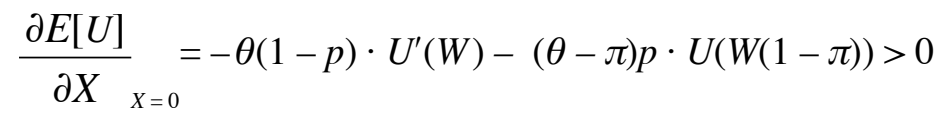

and

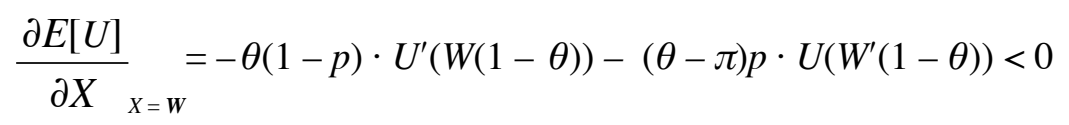

We can rewrite these conditions as:

$$
\begin{gathered}
p \pi>\theta\left[p+(1-p) \frac{U^{\prime}(W)}{U^{\prime}(W(1-\theta))}\right] \\
p \pi<\theta
\end{gathered}
$$

Expression [8] means that the taxpayer will evade if the probability of being audited multiplied by the penalty is lower than the tax rate. Both [7] and [8] guarantee an interior solution.

Other authors have introduced new elements to the basic Allingham and Sandmo (A-S) model. For example, Yitzhaki (1974) stated that the degree of tax evasion should decrease when the penalty rate $(\pi)$ or the probability of being audited $(p)$ increases. These results follow intuitive expectations and empirical evidence. This model also predicts a counterintuitive effect, which refers to the fact that the degree of tax evasion $(W-X)$ should decrease as the tax rate $(\theta)$ increases, although empirical results go in the opposite way and find that higher tax rates decrease the levels of compliance (Clotfelter, 1983; Hashimzade et al., 2013).

A common criticism to the A-S model and its extension is that they do not account for tax morale. It means that when the probability of being detected $(p)$ or the penalty rate $(\pi)$ is low enough, the agent's decision should be to underreport or evade taxes. The decision to evade should be even more obvious when there is no other source of information than the declared income of the individual itself. However, there is always a percentage of willful payment, which cannot be explained by the basic model (Alm, 2012). In order to correct some of these potential weaknesses, Traxler (2010) included in the A-S model the effect of social norms, which depends on the tax rate sensitivity of the taxpayer. 
Dhami and al-Nowaihi (2007) examine this particular aspect of the A-S model, namely, the surprisingly high levels of compliance that are not explained by the expected utility theory. According to their research, the levels of tax evasion should be greater if we consider the expected utility theory, given the relatively low audit probabilities and penalties. They propose an alternative theoretical model based on cumulative prospect theory. This model considers loss aversion with respect to a referred income, and it suggests that individuals tend to overweight small probabilities and to underweight large ones. Their theory seems to predict more precisely the extent of tax evasion when the audit probability and the penalty are low. Traxler (2010) incorporates the concept of tax morale as a social norm into the traditional model of tax evasion with the purpose of determining why taxpayers comply when the audit probability and fine are low. He claims that behavior is influenced by social norms related to compliance with a reference group. Additionally, Lago-Peñas and Lago-Peñas (2010) have found that sociodemographic characteristics, personal financial experiences, political attitudes and other variables also have an influence on tax morale.

Further theoretical extensions to the basic model are still grounded on its approach to crime and the expected utility theory. The variations include alternative functions to measure the effect of the imposed penalty, or incorporate more complexity and uncertainty on the fiscal parameters, make the labor supply endogenous, increasing the complexity of the income tax, and other. However, these models make more complex the statistics of fiscal compliance (Alm, 2012; Hashimzade et al., 2013).

Andreoni et al. (1998) review the literature changing the focal point to compliance instead of tax evasion. They also criticize the A-S model, as it assumes that the audit probability is constant and fixed ex-ante. On contrast, theoretical models predict the probability of being audited as a function of income, differentiating between two groups. The first group include principal-agent models where the audit probability is determined ex-ante by the public institution, and its decision has the objective of maximizing audit revenues. The second group refers to models where the audit probability is determined ex-post, after receiving the economic agents' declarations, and the decision is solved as a sequential game between the taxpayer and the government. Both types of models assume that taxpayers only provide information to the tax authorities on how much income they declare, though they also provide many other sources that can signal their level of tax compliance. Furthermore, in this study, the authors review the literature related to fiscal compliance and discuss three variables that seem to have an effect on it: moral rules, feelings of fairness toward the taxes or its prosecution, and taxpayer evaluation of government expenditure and corruption.

In this paper, we will pay special attention to the effect that this last variable, corruption, may have on tax evasion and compliance. 


\subsection{Mind the tax gap}

The tax gap is the difference between the quantity that taxpayers are obliged to pay by law, and the quantity they finally report and pay (Mazur et al., 2007). We can differentiate between tax gap coming from individual economic agents' reported taxes, like the income tax, and taxes related to firms, such as corporate taxes, sales taxes, value added taxes, property taxes and other. When estimating this gap, the literature shows different methods. Alm (2012) distinguishes between traditional and modern approaches. Regarding the traditional approaches, this author refers to direct vs. indirect methods.

The first direct method is based on random audits with the aim of detecting tax evaders. The main inconveniences of this method are that it is costly for the government; hence, the proportion of audits over the total sample of declarations cannot be very high. On the other hand, taxpayers may not know the probability of being audited by the authorities, which makes their decision rely on their risk aversion. In addition, when using this method, the computed level of tax evasion results from an estimation assuming that the rest of the tax filer population behaves in the same way as the audited sample does.

A second direct method to measure the tax gap is through surveys where subjects report if they evade or not. Moreover, this method provides information regarding sociodemographic and attitudinal variables (Andreoni et al., 1998). However, subjects participating in a survey where they have to self-report tax avoidance, have incentives to cheat if they think that their answers are potentially incriminating (Baumeister, 1982).

The last direct information on tax evasion may come from data originated from tax amnesties. Although the data obtained through this method detects real tax evasion, it only accounts for a small and unknown proportion of the evaded quantity in the whole economy. However, it can become a useful mean to recover part of the public revenues, and to make emerge black money from the shadow economy (Andreoni et al., 1998).

Regarding indirect methods, the literature has flourished in the last decades. One of the most common indirect approaches estimates tax evasion using the shadow economy as a proxy. The shadow economy has been defined as the set of economic activities that are not registered when computing the GDP of a country, but that would contribute to increase it if they were accounted for (Feige, 1994). It can be inferred through measurable data such as the electricity consumption, the currency demand, or national income accounts (Slemrod, 2007), and many other methods (e.g. MIMIC model, monetary approach, etc.).

Although the shadow economy and the levels of tax evasion in a country go hand in hand, these are not synonymous. There can be not declared economic activities that should count as part of the shadow economy, but it does not always imply that these activities would generate taxes, hence individuals in these cases could not be considered as tax evaders. In addition, there can be economic agents that declare 
their activity, but do not declare all their income. Hence, they would be tax evaders, but their activity should not count for the shadow economy estimations (FernándezLeiceaga et al., 2018).

Other indirect methods come from a behavioral economics approach. Pickhardt and Prinx (2014) review the behavioral dynamics of tax evasion and differentiate between four types of subgames depending on the economic agents that interact: taxpayers vs. taxpayers, taxpayers vs. authority, taxpayers with practitioners vs. authority, and tax lawmakers vs. taxpayers. For the present paper, we will focus on the second type of subgames, where relationships can be dominated by trust in the authorities from taxpayers' side (or vice versa), or by the power exerted from the authorities' side to detect and punish tax evasion (Kastlunger et al., 2013; Kogler et al., 2013).

This last approach includes both lab and field experiments. On one hand, lab experiments offer a controlled environment where the researcher can decide the audit probability, the quantity of the penalty, and many other variables. However, the results must be interpreted cautiously (Andreoni et al., 1998). On the other hand, some researchers have conducted controlled field experiments where the tax authorities send letters to taxpayers testing whether different pieces of information have an effect on the quantity of income reported (Slemrod et al., 2001; Iyer et al., 2010; Biddle et al., 2018). As the purpose of this paper is to focus on experimental trends, the next section provides some examples of the behavioral economics literature on tax compliance and evasion.

\subsection{Experiments on taxation}

\subsubsection{Lab experiments}

In the last decades, lab experiments in tax evasion have flourished with the purpose to combine economic and psychological theory with evidence (Pickhardt \& Prinz, 2014). The main advantage of conducting experiments in a lab is the possibility to control the process, as well as deciding ex-ante the audit probability, the quantity of the penalty, and the tax rate, among other variables. In addition, we can also decide the incentives that subjects will receive and establish quotas for the sample under study.

The usual process begins with the experimental design in which the researcher decides the number of treatments to be tested, and prepare the instructions for the experiment, usually using a neutral wording in order to avoid framing effects. Subsequently, recruited subjects are assigned to the various treatments. Participation can be incentivized with a fixed amount of money, providing subjects with an initial endowment, or with a variable amount, assigning the final payment based on the number of tasks and the results that participants perform during the experiment, or a mixture of both. Usually, a show-up fee is added to these incentives. The experimenter 
can also choose the matching protocol (i.e., one-shot or repeated) that fits better the studied (real-life) scenario. Repeated protocols simulate decisions that take place on regular basis. In this case, the experimenter can also decide whether to repeat the game using partner matching (meaning that the same partners or opponents play the game repeatedly over several repetitions) or stranger matching (the game is played repeatedly but matched to a different partner every round). In some experiments, the amount collected through taxes is assigned to a public good, what participants may benefit from at the end of the experiment.

Andreoni et al. (1998) review the main outcomes resulting from lab experiments since 1978. Alm (2012) also provides an extensive review on experiments conducted on tax compliance. Both papers find that lab experiments relate high tax rates with greater evasion, which contradicts the standard theory. Regarding the penalty rate and probability of being audited, both variables have a positive influence on compliance. This last result is in line with a meta-analysis conducted for 20 lab experiments (see Blackwell, 2007). In addition, the probability of being detected evading will raise the perception of being audited in the future, which will influence future tax compliance. This is a consequence of individuals making poor predictions on the probability of audit and penalty rates for evasion, tending to overestimate both of them.

One of the aspects that deserves further attention of the experiments conducted in labs is the fact that taxpayers do not always know the objective probability of an audit, but they have a subjective view of it, which is usually overestimated. It means that in lab experiments there is a higher compliance rate than what the expected utility theory predicts (Alm, 2012).

When comparing with empirical methods, lab experiments let the researcher introduce more variables in a controlled way and generate precise data on taxpayers' decisions. However, external validity of results can be questioned. Hence, results must be interpreted cautiously, and replications are needed to establish sufficiently grounded conclusions (Alm, 2012).

\subsubsection{Field experiments}

Empirical studies on tax evasion can circumvent the question of external validity of experimental methods. However, as mentioned before, this method does not let the researcher the freedom to introduce or omit variables, and reduces the level of control exerted by the experimenter.

Most field studies test the effects of potential determinants of compliance by using a physical letter. The common procedure is to send a "deterrence letter", carefully designed according to the objective of the study, to a (randomly) selected set of taxpayers from behalf of the tax authority. Then, the results of tax compliance are compared with a control group or with the behavior of the same subjects in a previous period. The novelty of this method was that the letters were sent directly from the revenue administration, therefore the experiment captures real behavior. Secondly, 
it does not change the rules (the legislation), the letters only mean to increase the perceived probability of audit or to make taxpayers aware of their obligations and the consequences of their compliance decisions.

Blumenthal et al. (2001) conducted a first field experiment in Minnesota assessing the effects of two letters with normative appeals compared to a control group. Though, they found no treatment effect, letters seemed to impact tax compliance for some groups of taxpayers.

In a second experiment in Minnesota, the tax authority sent letters to a group of taxpayers that was selected along two dimensions: income and opportunity to evade. The letters notified these individuals that they had been selected to be part of a study and that their tax declarations would be "closely examined". The letters had a significant impact on reported income, although the effect varies across categories: tax revenues increased for low and middle-income taxpayers (combined with high evasion opportunity the effect is stronger than for those with low-opportunity), but the result was the opposite for high-income taxpayers (Slemrod et al., 2001). Following this point, Kleven et al. (2011), in a field experiment conducted in Denmark, found that letters warning about the possibility of being audited had a significant effect on self-reporting taxpayers increasing their tax compliance, but it had no effect on third-party workers.

Carrillo et al. (2013) evaluate the effectiveness of deterrence letters in Argentina, combining the usual factors (probability of audit and penalties) with equity and fairness. In their treatments the deterrence message is much softer than in the previously mentioned articles. They find that except of the letters influencing the perceived probability of audit and the penalties for evasion, the studied factors do not have a significant effect on compliance.

In another study conducted in Washington State, researchers sent letters to firms with the purpose of testing the effects of an increased perceived detection risk and/ or the awareness of penalty $(2 \times 2$ design $)$. They found that penalty-related letters lead to an increase in the declared income (used as the base for calculating tax obligations). The detection and penalty manipulations showed significant effects for taxpayers with decreasing revenues, but not for taxpayers with increasing revenues (Iyer et al., 2010).

Torgler $(2004,2013)$ conducted two studies in Switzerland to test the effect of moral persuasion on tax compliance. The researcher found hardly any effect on taxpayers' compliance behavior in any of the field experiments.

In Australia, the tax authorities conducted two field experiments with the purpose of nudging businesses to comply with their tax obligations. In the first study, they found no significant effect after changing internal guidelines used by field auditors to raise awareness of the relevance of tax debt payments. In the second study, however, they found that simplifying a follow-up letter sent to the firms and changing the phone script of desk auditors reduced the proportion of default assessment. While the previous studies were concerned about finding the most effective content of the letters sent to the taxpayers, some recent studies ask what the most effective 
way to deliver the message is. Nowadays most tax administrations have a great variety of ways to communicate with their clients besides physical letters: e-mails, SMS, phone-calls, messages, or personal visits. Doerrenberg and Schmitz (2015) carried out a field experiment, sending the same message (combining deterrence and moral suasion) to small firms by post or through the personal visit of a tax official. Compared to a non-treated control group, both treated groups report a higher taxable income but the differences (probably due to the relatively small sample size) are not significant. In another experiment, Ortega and Scartascini (2016) circumvent the problem of sample size and test the effectiveness of three delivery methods: letters, e-mails and personal visits, sharing exactly the same message with taxpayers, in any of the three cases. They find that all three methods are effective in encouraging the payment of outstanding tax liabilities, but personal visits are extraordinarily successful. Given that most tax administration do not have the capacity to employ this highly expensive but very effective method to increase tax compliance, the authors recommend a combined use of the existing delivery methods in order to achieve large revenue gains.

Although the literature on field experiments is large, given the differences in design and methodology, it seems to be difficult to find robust and meaningful effects as to compare to those of laboratory experiments. In addition, the method and the context in which field experiments are conducted makes it more difficult to obtain reliable information from the participants on the reasons behind the found effects. Though, both lab and field experiments suggest that raising either the fine or the (perceived) probability of audit will usually increase tax compliance.

On the other hand, most field and lab experiments assess the immediate effects of the treatments, only a few papers (Carrillo et al., 2016; Dunning et al., 2016; Manoli \& Turner, 2014) raise the question of longer-term effects and sustainability. In general, they suggest that the learning effects of the treatments are short-term (no longer than 3 years), therefore, to maintain the achieved compliance levels, regular communication between the tax administration and the taxpayers would be advisable. Importantly, learning in real life situations can happen through a different channel as well. As some recent articles highlight it, learning can not only happen through the official channels, but also on one's social network. Alstadsaeter et al. (2014) and Drago et al. (2015) show evidence on this kind of learning, and emphasize the importance of the found large spillover effects: non-treated taxpayers who form part of the same social network as some treated one, were more likely to increase tax compliance. Surprisingly, these spillover effects were as large as the direct treatment effects. These results have important policy implications and open new lines of research in order to make better use of the resources. 


\section{Fraud/Corruption}

Corruption and tax fraud have been studied separately in the literature for a long time, and already their effects on the economy are considerable. Although earlier research claimed that corruption may increase efficiency (Leff, 1964; Huttington, 1968), a broad set of empirical evidence shows the dramatic effects that corruption and fraud have on a country's social and economic development. Corruption and fraud hinder economic growth (for example, Fisman \& Svensson, 2007; Meon \& Sekkat, 2005) and increase poverty and inequality (Gupta et al., 1998; Olken, 2006). But there is no doubt that -as fiscal contract theories hypothesize- tax compliance is deeply intertwined with the political environment that influences the social contract between the citizens and the government. Clearly, taxpaying is the result of both a quasi-voluntary compliance and (costly) law enforcement, and both components can be affected by the degree of perceived or revealed corruption. Low corruption and government accountability have been emphasized as the pre-requisites for a country's successful tax performance (Bird et al., 2008).

Economic theory of corruption has focused on the design of institutions that can prevent public officials from abusing their position. Theoretical models suggest that when private returns to corruption are high, or when the probability or consequences of detection are limited (for example due to weak institutions or capacity constraints), individuals are more bound to act corruptly. Therefore, such institutions should set up a system of rewards and punishments that render the expected return of corruption lower than the returns to truthful behavior. Hence, the (early) literature on corruption theory focuses on the wages of public officials, the principal's monitoring capacity (that will determine the detection probability), and other possible penalties. More recent studies show, that as the proportion of corrupt individuals in a society increases, it gets easier (and cheaper) to find a partner with whom to engage in a corrupt transaction and escape detection and/or punishment. This, in turn, results in multiple equilibria involving different levels of corruption, and a country can find itself in a corruption trap, from which it is extremely difficult to escape. Moreover, as Hauk and Saez-Marti (2002) show, the level of corruption in a society might influence younger generations' values and attitude towards corruption. Of course, monitoring and incentive systems, together with the government's commitment keep being important pillars in the fight against corruption. Recent theories suggest that well-designed leniency programs can decrease the cost of monitoring and prosecuting corruption. On the other hand, uncertainty regarding the corruptibility of one's partner can also prevent agents from corrupt decisions (Ryvkin \& Serra, 2012), therefore solutions like staff-rotation gained attention in recent (tax) administration reforms.

Corruption, besides the economic perspective, has a second dimension, studied by psychologists and cultural anthropologists. They argue that besides the external incentives, intrinsic motivations (like reciprocity, shame, guilt for breaking some social norms, culture, etc.) also play an important role in an individual's choice between 
honesty and corruption. Intrinsic motivations are the results of the internalization of social norms, but social norms vary across societies, therefore different policies might be needed in different societies. Moreover, some results suggest that in some cases the external incentives (namely, sanctions) aimed at deterring corruption are counterproductive, as they crowd out intrinsic motivations. What before was a question of right or wrong, now becomes a simple decision problem where the calculus of risks and benefits determines the choice.

In summary, we can see that the theory of corruption studies the phenomena in two interrelated dimensions: on one hand, on individual level, studying the incentives of an agent to engage in a corrupt activity -usually modelled with some kind of bribery game- and on aggregate level, assessing the role of the society. Although the theoretical results are derived in a general setting, they have important implications when applied for the tax administration.

\subsection{Empirical results on corruption and tax compliance}

There is now a vast and growing empirical literature analyzing the determinants of tax compliance, suggested by the theory, but only a small part of this literature accounts for its relation to corruption, generally on aggregate, or firm level. Given the secretive nature of corrupt interactions, it is difficult to study in the field the determinants and possible solutions to it in a reliable way. Several important drawbacks of the empirical studies should make us careful when evaluating their findings. First, these are usually cross-country econometric studies, that use subjective measures of corruption and might carry important measurement errors. Moreover, the results of different authors often contradict each other, possibly due to different measures, empirical specifications, or some problems with the data set (multicollinearity, omitted variable bias, etc.). Some factors that might be decisive in measuring the degree of corruption of a country (like democratic institutions, level of development, etc.) are endogenous to the existing level of corruption. Finally, from the cross-country econometric studies we do not get information on individual decisions on corrupt behavior. Naturally, collect information in the field about corruption on individual level is complicated as it involves illegal acts and the agents engaged in such activities would rather prefer to hide their participation.

Recent literature uses alternative methods to measure corruption in the field in a more accurate and reliable way. The idea is to measure corruption as the "missing money". These methods include for example the comparison of administrative data on public funds obtained at different levels of the government (Reinnika \& Svensson, 2004), records of exported and imported goods produced by the exporting and importing country (Fisman \& Wei, 2004), or data of corruption audits of different years (Ferranz \& Finan, 2011). Although these field studies increased the understanding of the factors and costs of corruption in some settings, only a few rely on direct corruption measures (Sequeira, 2012; Olken \& Barron, 2009). 
As we mentioned above, field studies on corruption in the domain of tax compliance are scarce and concentrate on aggregate data. Despite all the difficulties that we discussed before regarding the study of corrupt behavior, the advantage of these studies is that the analyzed data comes from real taxpaying decisions. Most empirical papers study the determinants and consequences of corruption (in the country or in the tax administration) on the tax revenues, usually in developing countries.

Fjeldstad (2005) studies the experiences in the fight against corruption in the Uganda Revenue Authority (URA). Similarly to a number of countries in Latin America, the reform in the tax administration appeared to be successful in the first years, meaning a significant increase in the tax revenues and decline in corruption. However, these positive changes vanished in the following years. The main explanations for this change are the public perception of a high level of corruption, some external factors, like general economic trends, import restrictions, or the decreased staff productivity due to lack of motivation. However, there are many indications that an increase in fiscal corruption has contributed to the fall in the reported revenues. The study points out that corruption and tax evasion seem to increase in all levels of the URA, and even the number of tax officials openly demanding bribes has increased. The article identifies several factors that contributed to this situation: declining wages; bonus systems and revenue targets; the used policy to hire and (not) fire workers at operative levels; human resource management and job insecurity that affected primarily the managers, and turned out to increase their corruptibility; political interference; patronage and taxpayers' low compliance often due to their eroded confidence in the fairness and impartiality of the tax administration. The paper concludes that in an environment where there is a huge demand for corrupt services and monitoring -due to different factors- is ineffective, higher wages rather than restraining corruption might work as a bonus on top of the bribes taken by corrupt officers. One of the reasons behind this is the impact of social and family networks over which the URA has no influence. Therefore, one of the challenges to increase the efficiency is to change the impact of traditional values and social obligations on the behavior of public officials. On the other hand, the complicated and non-transparent tax structure, together with the lack of taxpaying culture in the country also represent an obstacle to building a stable, long-term revenue base in Uganda.

Timmons and Garfias (2015) use randomized auditing reports from the Brazilian federal government to study the effects of information about corruption on firms' property tax reports. Besides analyzing the relation between revealed corruption and tax revenues, they also relate these issues with fiscal accountability and the likelihood of adopting Participatory Budgeting (PB). Their main objective is to understand the role of information on tax collection and government performance. The authors test the hypothesis that the use of PB (i.e., increased and direct citizens' control over resource allocation) would decrease government corruption, improve government performance and increase the satisfaction of the society, therefore raise tax revenues. 
In other words, on one hand, revealed corruption should incentivize the adoption of PB and other fiscally accountable institutions, and on the other hand, tax revenue should increase with good reports on corruption (and decrease with bad reports). These hypotheses are confirmed by the data, but importantly, the changes in property tax revenue are only experienced on the short run. Therefore, repeated access to (reliable) audit reports should be granted to citizens in order to maintain the achieved results. The data also confirms that revealed corruption increases the probability of adoption of PB.

Uslaner (2010) studies empirically the relation between firm tax evasion and corruption in some transition countries during 2002-2005, based on surveys of businesspeople (not ordinary citizens) in 26 formerly communist countries. These countries are, most probably partially due to communist heritage, different from the West: tax morale is rather low, the shadow economy is much greater, the corruption is far worse, the quality of basic (public) services is poor, the legal system is generally seen as unfair, and economic inequality is -although already higher than in the Westgrowing. Therefore, the people in transition countries see corruption as long-term, insoluble problem -although in many cases, corruption in the course of one's duties (like gift payments, gratitude money) is not even perceived as immoral. The results of the paper confirm that the perception of the quality of government services and the degree of corruption play a key role in tax compliance. Other factors, like the size and ownership of the firm, the fairness of the legal system, the tax rate, or the perceived probability of audits also matter but to a smaller extent.

In a recent paper with wider focus, Alm et al. (2016) use firm-level data on tax reporting to study how the potential for bribery of tax officials affects the tax report of a firm. Their empirical framework assumes that the firm decides how much to report, taking into consideration that bribing a corrupt official is also possible. Their results confirm the argument that the quality of the tax enforcement is one of the prime determinants of tax compliance. They find that corruption of tax officials is a significant determinant of tax evasion, as with corrupt tax officials the reported sales (for taxes) reduce significantly. Moreover, the higher the bribes required, higher the level of tax evasion. Therefore, they conclude that governments seeking to fight tax evasion, and increase the tax revenues should first ensure the honesty of the tax administration.

The issue of the relation between public service delivery and tax compliance has been studied in field experiments as well, although typically with a different focus and inconclusive results. They generally find little support for its effectiveness in increasing tax compliance, revealing either no effect (Ariel, 2012) or much smaller effect than other moral appeals (Bott et al., 2014; Hallsworth et al., 2017). However, others (Castro \& Scartascini, 2013; Carrillo et al., 2016) find some evidence that suggest that a higher level of public goods provision is associated with a higher tax compliance.

To our best knowledge, there are no empirical papers that relate directly corruption and tax compliance on individual level. In this aspect, laboratory experiments can 
contribute effectively to our understanding of the factors that affect individual decisions related to tax payments in the presence of corruption.

\subsection{Laboratory experiments}

Laboratory experiments are able to create scenarios that mimic real-life situations combining corruption and individual tax decisions. The use of experimental methods and data gathering can be parallel to the collection of field data, as the advantages of one method are the drawbacks of the other, and vice versa. In laboratory experiments the data is obtained in a controlled, though highly stylized and artificial, environment and the experimenter has control over many individual factors that can be tested while keeping all others constant. Taking into account that individual tax decisions including dishonest behavior (like engaging in corruption) are difficult to observe in real-life data, laboratory experiments can result very useful. Although there are very few experimental studies that relate explicitly corruption with individual tax decisions and tax compliance, the results of the existing experimental literature on corruption in general can be relevant in this area as well. Since corruption has many facets, experimentalists modelled it in many different ways, according to the studied situation and the objectives of the study. Hence, although this results in a higher diversity, it also means that there is no consensus either on the design or on the policy implications of the results.

A bunch of experimental studies on corruption test the institutional factors suggested by the theory. Bribery (i.e., private payment to a public official in exchange of a benefit or the avoidance of some cost) in most countries is considered an illegal act and is persecuted by the governments, although the probability of detection and the consequences vary significantly across the world. Bribery can be seen as a trust game between the briber and the bribe, as there is no legal contract between the involved agents, due to the illegality of the act. The effects of being detected and the consequent punishment on the individual decisions can be neatly studied in the lab in a controlled environment.

Abbink et al. (2002) model bribery as a situation of undesirable reciprocity. They implement in the lab a simple two-player, three-stage bribery game with three treatments, in order to isolate the effect of (i) the reciprocal relation between agents, (ii) the negative externality on the public, and (iii) the severe punishment when being caught. The reciprocity is identified through the extent of exchange of favors, that are individually beneficial but harmful to the public thus prohibited. To isolate the negative externality caused to the others, in the second treatment the reciprocal answer to the bribe inflicts costs on others. In the third treatment, authors add a severe punishment that the corrupt agents suffer when caught. Their results show that the costs inflicted on others do not affect neither the average bribe, nor the average number of reciprocal choices. However, the possibility of a severe punishment acts as a strong deterrence factor against corruption. 
In a follow-up study Abbink (2004) studies the effect of staff rotation on corrupt behavior, simply re-matching partners in each round in the above described bribery game, repeated over 30 rounds. He finds that both average bribes and the average number of reciprocal choices decreased, the effect on the latter being stronger. On the other hand, the effects over time can not be detected. This suggests that staff rotation can be a powerful tool in reducing bribery, but the effects are short run and the frequent reallocation of public officials might cause extra costs and efficiency losses (both on individual and institutional level).

Schulze and Frank (2003) conduct a lab-in-field kind experimental bribery game without strategic interaction. Participants had to make an individual decision in a hypothetical situation, choosing the size of the bribe that came included in the decision. In their setting, the probability of detection of the corruption increases with the size of the bribe, and a penalty is applied when corruption detected. Compared to the case without penalty, the detection mechanism does not reduce the frequency of bribery, it only shifts the distribution of bribes to the moderate levels, eliminating the very high bribes and the honest decisions as well. Hence, the authors find evidence on a crowding out of intrinsic motivation.

Berninghaus et al. (2013) study the corrupt behavior of public officials in a game, where corruption is modelled as a coordination game. In the game public officials have to choose between a safe (honest) option with a fixed return and a risky (corrupt) one that yields zero payoff if the corrupt decision is discovered and a high payoff if not. The probability of getting caught depends negatively on the number of corrupt officials, mimicking the empirical observation that in a corrupt society, dishonest officials have less to fear than in one where corruption is seen immoral. In this setting, two pure-strategy equilibria exist in which either no-one or everyone is corrupt. The authors find that beliefs are a stronger factor than risk attitudes in predicting a subject's propensity of becoming corrupt.

Serra (2011) studies a two-stage bribery game without reciprocity: in the first stage the public official can ask for a bribe, and in the second stage the client decides whether or not to pay it. In the first case the decision that favors the client is automatically implemented, which in turn inflicts negative externalities on some passive players (citizens). The paper analyzes two treatments, representing two approaches to combat corruption: in the first treatment the probability of getting punished when asking for a bribe is fixed; while in the second treatment, the probability of getting caught is still $4 \%$, but this lottery is only played out if a client reports the official's request for bribe to the authorities. The author finds that bribe demands are significantly lower in the second treatment despite the lower risk of suffering a penalty, but unfortunately the data -due to the design of the experimentis not able to explain the reasons of this observation.

A partially related situation is studied in Schikora (2011), who studies the effects of whistle blowing with and without leniency in the lab. In their experiment, fixed pairs of players interact repeatedly for the provision of a service in a neutrally described situation. Any of the two agents can initiate a corrupt transaction by 
either offering or demanding a bribe in the different stages of the game. If a bribe is paid, the bribe can (but is not obliged to) reciprocate it. This reciprocity represents a corrupt decision, causing negative externalities on other participants, which are also involved in the same experiment on decision-making. This baseline treatment is compared with symmetric and asymmetric whistle-blowing treatments. In the first treatment any of both agents can blow the whistle when a corrupt act is observed, and the consequences are the same for both agents (independently of who blew the whistle). With asymmetric whistle-blowing the bribee is granted leniency and only the briber suffers the consequences. The author finds that while giving the briber the possibility to blow the whistle against a corrupt official that demanded a bribe is effective in reducing corruption, the briber can also use whistle-blowing as a threat to force the official to reciprocate. On the other hand, whistle-blowing with asymmetric leniency reduces corruption significantly.

Buckenmaier et al. (2018) study collusive corruption within a tax evasion framework in the bribery game introduced in Abbink et al. (2002). In the basic game without leniency, each taxpayer receives a fixed income and is taxed at a fixed rate that has to be reported to a tax official. In this design, underreporting requires the cooperation of the tax official who can be offered a bribe for the assistance in evading taxes. The reports are audited with a fixed probability and in caught, a penalty is paid by the taxpayer but there are no consequences for the tax official. Leniency program is added in an additional stage, where taxpayer can report the corrupted tax official during an audit and avoid the pending penalty, while the official has to pay a fine. With these rules, the risk of being caught and fined is borne exclusively by the tax official. The authors find that in the presence of leniency, the successful collusion between the agents is less frequent than in the baseline game. This result is driven by the low willingness of tax officials to accept bribes, which in turn translates in less evasion and higher tax revenues. On the other hand, the removal of the leniency program does not cause the opposite effect, suggesting that the positive spillover effects of leniency remain even after the mechanism has been removed.

The relation between public officials' wages and corruption (namely, that higher salaries lead to lower corruption) has also been studied by several laboratory experiments. Van Veldhuizen (2011) studies the bribery game of Abbink et al. (2002) with modified relative payoffs between bribers and officials. Moreover, in this case the negative externalities are deducted from a donation to a charity of the subject's choice that the experimenter makes. The results show that corrupt decisions made by officials with high wages are significantly lower than that of their lowwage counterparts. Similar wage effects were found in experiments in the context of embezzlement (Azfar \& Nelson, 2003; Barr et al., 2009) and also in the field (Armantier \& Boly, 2011).

The role of non-monetary incentives and intrinsic motivations in deterring corruption has also attracted attention in the experimental literature, although not in specific tax-related issues. Different experimental studies that assess the possible effects of framing in corrupt situations (i.e., enhancing participants' awareness of the 
corrupt nature of the actions) arrive to contradictory conclusions (Abbink \& HennigSchmidt, 2006; Barr \& Serra, 2009), thus suggesting that the effects of framing depend on the particular experimental setting. On the other hand, as we already mentioned it in some of the previous papers, (negative) externality caused by corrupt decisions seems to have no importance in the decision-making.

\section{Conclusions}

Taxation policies may reveal much about a country's political context. Taxation not only raises revenue for public spending to fight poverty. It can also redistribute wealth and opportunities, diminishing inequalities and strengthening state-society relations by boosting citizens' ability to demand greater accountability.

In this paper we summarize the recent advances in the experimental literature on tax compliance and corruption, presenting both laboratory and field studies. The experimental study of tax compliance in the presence of corruption is an interesting and important question, given the advantages that the controlled environment offers when analyzing activities that in real life are practically unobservable due to its highly secretive nature. The objective of these laboratory experiments can be to test the predictions of the vast theoretical literature on the determinants of tax compliance (with or without corruption), to collect and analyze direct, micro-level data that in the field would be impossible to get, and compare with the available (real-data) measures in order to give policy recommendations. In this line, future experimental research would be needed to produce controlled data to understand the relation between tax compliance on individual level and corruption, where the decision task is clearly and directly related to different levels or forms of corruption. This would help to evaluate the importance of the factors suggested by theory and understand their interaction with the individual tax decisions. Based on robust results backed by theory, field and laboratory data, useful and reliable policy recommendations can then be formulated in order to achieve (and maintain) a higher tax compliance, lower corruption and hence, higher tax revenues.

\section{References}

Abbink, K., Irlenbusch, B., \& Renner, E. (2002). An experimental bribery game. Journal of Law, Economics, and Organization, 18(2), 428-454.

Abbink, K. (2004). Staff rotation as an anti-corruption policy: an experimental study. European Journal of Political Economy, 20(4), 887-906.

Abbink, K., \& Hennig-Schmidt, H. (2006). Neutral versus loaded instructions in a bribery experiment. Experimental Economics, 9(2), 103-121.

Acconcia, A., D'Amato, M., \& Martina, R. (2003). Corruption and tax evasion with competitive bribes (Working Paper, No. 112). Centre for Studies in Economics and Finance. 
Aidt, T. S. (2011). Corruption and sustainable development. International handbook on the economics of corruption, 2, 3-51.

Allingham M., \& Sandmo A. (1972). Income tax evasion: a theoretical analysis, Journal of Public Economics, 1(3-4), 323-338.

Alm, J. (2012). Measuring, explaining, and controlling tax evasion: lessons from theory, experiments, and field studies. International Tax and Public Finance, 19(1), 54-77.

Alm, J., Martinez-Vazquez, J., \& McClellan, C. (2016). Corruption and firm tax evasion. Journal of Economic Behavior \& Organization, 124, 146-163.

Alstadsaeter, A., Kopczuk, W., \& Telle, K. (2014) Social networks and tax avoidance: evidence from a well-defined Norwegian tax shelter. Mimeo. University of Oslo, Columbia University, and Statistics Norway.

Andreoni, J., \& Miller, J. (2002). Giving according to GARP: An experimental test of the consistency of preferences for altruism. Econometrica, 70(2), 737-753.

Andreoni, J., Erard, B. \& Feinstein, J. (1998). Tax Compliance. Journal of Economic Literature, 36(2), 818-860.

Ariel, B. (2012). Deterrence and moral persuasion effects on corporate tax compliance: findings from a randomized controlled trial. Criminology, 50(1), 27-69.

Armantier, O., \& A. Boly (2011). Can Corruption be Studied in the Lab? (Working paper). University of Montreal.

Azfar, O., \& Nelson, W. R. (2007). Transparency, wages, and the separation of powers: An experimental analysis of corruption. Public Choice, 130(3-4), 471-493.

Baumeister, R. F. (1982). A self-presentational view of social phenomena. Psychological bulletin, 91(1), 3 .

Barr, A., Lindelow, M., \& Serneels, P. (2009). Corruption in public service delivery: An experimental analysis. Journal of Economic Behavior \& Organization, 72(1), 225-239.

Barr, A., \& Serra, D. (2009). The effects of externalities and framing on bribery in a petty corruption experiment. Experimental Economics, 12(4), 488-503.

Barr, A., \& Serra, D. (2010). Corruption and culture: An experimental analysis. Journal of Public Economics, 94(11-12), 862-869.

Becker, G. S. (1968). Crime and punishment: An economic approach. In The economic dimensions of crime (pp. 13-68). Palgrave Macmillan.

Beekman, G., Bulte, E., \& Nillesen, E. (2014). Corruption, investments and contributions to public goods: Experimental evidence from rural Liberia. Journal of Public Economics, 115, 37-47.

Berninghaus, S. K., Haller, S., Krüger, T., Neumann, T., Schosser, S., \& Vogt, B. (2013). Risk attitude, beliefs, and information in a Corruption Game-An experimental analysis. Journal of Economic Psychology, 34, 46-60.

Besley, T., \& McLaren, J. (1993). Taxes and bribery: the role of wage incentives. The Economic Journal, 103(416), 119-141.

Biddle, N., Fels, K. M., \& Sinning, M. (2018). Behavioral insights on business taxation: Evidence from two natural field experiments. Journal of Behavioral and Experimental Finance, 18, 30-49.

Bird, R. M., Martinez-Vazquez, J., \& Torgler, B. (2008). Tax effort in developing countries and high income countries: the impact of corruption, voice and accountability. Economic Analysis and Policy, 38(1), 55-71. 
Blackwell, C. (2007). A meta-analysis of tax compliance experiments (Working Paper No. 0724). International Center for Public Policy, Andrew Young School of Policy Studies, Georgia State University.

Blumenthal, M., Christian, C., Slemrod, J., \& Smith, M. G. (2001). Do normative appeals affect tax compliance? Evidence from a controlled experiment in Minnesota. National Tax Journal, 125-138.

Bott, K., Cappelen, A. W., \& Sørensen, E. Ø. (2014). You've got mail: a randomised field experiment on tax evasion (Discussion Paper 26/2014). Department of Economics, Norwegian School of Economics.

Buckenmaier, J., Dimant, E., \& Mittone, L (2018). Effects of institutional history and leniency on collusive corruption and tax evasion. Journal of Economic Behavior and Organization. https://doi.org/10.1016/j.jebo.2018.04.004

Carrillo, P., Castro, E., \& Scartascini, C. (2016). Do rewards work to maintain and increase tax compliance? Evidence from the randomization of public goods. World Bank ABCDE 2016 Conference, World Bank, Washington, DC.

Castro, L., \& Scartascini, C. (2013). Tax compliance and enforcement in the Pampas: evidence from a field experiment. Journal of Economic Behavior and Organization, 116, 65-82.

Chander, P., \& Wilde, L. (1992). Corruption in tax administration. Journal of Public Economics, 49(3), 333-349.

Choi, J. P., \& Thum, M.(2005). Corruption and the shadow economy. International Economic Review, 46(3), 817-836.

Clotfelter, C. T. (1983). Tax evasion and tax rates: An analysis of individual returns. The Review of Economics and Statistics, 363-373.

Dell'Anno, R. \& Schneider, F. (2004). The Shadow Economy of Italy and other OECD Countries: What Do We Know? (Discussion Paper). Department of Economics, University of Linz.

Dhami, S., \& Al-Nowaihi, A. (2007). Why do people pay taxes? Prospect theory versus expected utility theory. Journal of Economic Behavior \& Organization, 64(1), 171-192.

Doerrenberg, P., \& Schmitz, J. (2015). Tax compliance and information provision: a field experiment with small firms (IZA Discussion Papers 9013). Institute for the Study of Labor (IZA).

Drago, F., Mengel, F., \& Traxler, C. (2015). Compliance behavior in networks: evidence from a field experiment (IZA Discussion Paper 9443). Institute for the Study of Labor (IZA).

Dunning, T., Monestier, F., Pi neiro, R., Rosenblatt, F., \& Tu n'on, G. (2016). Is paying taxes habit forming? Experimental evidence from Uruguay. Mimeo.

Faruq, H., Webb, M., \& Yi, D. (2013). Corruption, Bureaucracy and Firm Productivity in Africa. Review of Development Economics, 17(1), 117-129.

Feige, E. L. (1994). The underground economy and the currency enigma. Public Finance= Finances publiques, 49 (Supplement), 119-136.

Fernández-Leiceaga, X., Lago-Peñas, S., Martínez-Vázquez, J., \& Vaquero-García, A. (2018). Economía sumergida y fraude fiscal en España: ¿Qué sabemos? Una panorámica de la literatura. En S. Lago Peñas (Ed.), Economía sumergida y fraude fiscal en España: ¿Qué sabemos? ¿Qué podemos hacer? (pp. 17-41). Funcas-Estudios de la Fundación.

Ferraz, C., \& F. Finan (2011). Electoral Accountability and Corruption: Evidence from the Audits of Local Governments. American Economic Review, 101(4), 1274-1311. 
Fisman, R., \& J. Svensson (2007). Are corruption and taxation really harmful to growth? Firm level evidence. Journal of Development Economics, 83(1), 63-75.

Fisman, R., \& S. J. Wei (2004). Tax Rates and Tax Evasion: Evidence from Missing Imports in China. Journal of Political Economy, 112(2), 471-500.

Fjeldstad, O. H. (2005). Corruption in tax administration: lessons from institutional reforms in Uganda. In S. Rose-Ackerman (Ed.), International handbook on the economics of corruption (pp. 484-511). Edward Elgar Publishing.

Gupta, S., et al. (1998). Does Corruption Affect Income Inequality and Poverty (Working Paper No. 98/76). International Monetary Fund.

Habib, M., \& Zurawicki, L. (2002). Corruption and foreign direct investment. Journal of International Business Studies, 33(2), 291-307.

Hallsworth, M. et al. (2017) The behavioralist as tax collector: using natural field experiments to enhance tax compliance. Journal of Public Economics, 148, 14-31.

Hashimzade, N., Myles, G. D., \& Tran-Nam, B. (2013). Applications of behavioural economics to tax evasion. Journal of Economic Surveys, 27(5), 941-977.

Hauk, E., \& Saez-Marti, M. (2002). On the cultural transmission of corruption. Journal of Economic theory, 107(2), 311-335.

Hindriks, J., Keen, M., \& Muthoo, A. (1999). Corruption, extortion and evasion. Journal of Public Economics, 74(3), 395-430.

Huttington, S. P. (1968). Political order in changing societies. Yale University Press.

Iyer, G. S., Reckers, P. M., \& Sanders, D. L. (2010). Increasing tax compliance in Washington state: A field experiment. National Tax Journal, 63(1), 7.

Justesen, M. K., \& Bjørnskov, C. (2014). Exploiting the poor: Bureaucratic corruption and poverty in Africa. World Development, 58, 106-115.

Kahneman, D., Knetsch, J. L., \& Thaler, R. (1986). Fairness as a constraint on profit seeking: Entitlements in the market. The American Economic Review, 728-741.

Kastlunger, B., Lozza, E., Kirchler, E., \& Schabmann, A. (2013). Powerful authorities and trusting citizens: The Slippery Slope Framework and tax compliance in Italy. Journal of Economic Psychology, 34, 36-45.

Kleven, H. J., Knudsen, M. B., Kreiner, C. T., Pedersen, S., \& Saez, E. (2011). Unwilling or unable to cheat? Evidence from a tax audit experiment in Denmark. Econometrica, 79(3), 651-692.

Kogler, C., Batrancea, L., Nichita, A., Pantya, J., Belianin, A., \& Kirchler, E. (2013). Trust and power as determinants of tax compliance: Testing the assumptions of the slippery slope framework in Austria, Hungary, Romania and Russia. Journal of Economic Psychology, 34, 169-180.

Lago-Peñas, I., \& Lago-Peñas, S. (2010). The determinants of tax morale in comparative perspective: Evidence from European countries. European Journal of Political economy, 26(4), 441-453.

Leff N. H. (1964). Economic development through bureaucratic corruption. American Behavioral Scientist, 8, 8-14.

Manoli, D. S. \& Turner, N. (2014). Nudges and learning: evidence from informational interventions for low income taxpayers (Working Paper No. 20718). National Bureau of Economic Research.

Mazur, M. J., Plumley, A. H., \& Plumpley, A. H. (2007). Understanding the tax gap. National Tax Journal, 569-576. 
Meon, P., \& G. Sekkat (2005). Does corruption grease or sand the wheels of growth? Public Choice, 122, 69-97

Mossin, J. (1968). Taxation and risk-taking: an expected utility approach. Economica, 35(137), 74-82.

Olken, B. (2006). Corruption and the cost of redistribution. Micro evidence from Indonesia. Journal of Public Economics, 90, 853-870.

Olken, B.A., \& Barron, P. (2009). The simple economics of extortion: evidence from trucking in Aceh. Journal of Political Economy, 117(3), 417-452.

Ortega, D., \& Scartascini, C. (2016). Don't blame the Messenger: a field experiment on delivery methods for increasing tax compliance. Mimeo. Inter-American Development Bank

Pickhardt, M., \& Prinz, A. (2014). Behavioral dynamics of tax evasion-A survey. Journal of Economic Psychology, 40, 1-19.

Reinikka, R., \& Svensson, J. (2004). Local capture: evidence from a central government transfer program in Uganda. The Quarterly Journal of Economics, 119(2), 679-705.

Ryvkin, D., \& D. Serra (2012). How corruptible are you? Bribery under uncertainty. Journal of Economic Behavior and Organization, 81, 466-477.

Sanyal, A., Gang, I. N., \& Goswami, O. (2000). Corruption, tax evasion and the Laffer curve. Public Choice, 105(1-2), 61-78.

Schickora, J. T. (2011). Bringing good and bad whistle-blowers to the lab (No. 2011-4). Munich discussion paper.

Schneider, F. (2015). Schattenwirtschaft und Schattenarbeitsmarkt: Die Entwicklungen der vergangenen 20 Jahre, Perspektiven der Wirtschaftspolitik 16(1), 3-25.

Schulze, G., \& B. Frank (2003). Deterrence versus Intrinsic motivation: Experimental evidence on the determinants of corruptibility. Economics of Governance, 4, 143-160.

Sequeira, S. (2012). Advances in Measuring Corruption in the Field. In D. Serra and L. Wantchekon (Eds.), New Advances in Experimental Research on Corruption. Research in Experimental Economics Volume 15. Emerald Group Publishing.

Serra, D. (2011). Combining top-down and bottom-up accountability: Evidence from a bribery game. Journal of Law, Economics and Organization, 28, 569-587.

Slemrod, J. (2007). Cheating ourselves: The economics of tax evasion. Journal of Economic Perspectives, 21(1), 25-48.

Slemrod, J., Blumenthal, M., \& Christian, C. (2001). Taxpayer response to an increased probability of audit: evidence from a controlled experiment in Minnesota. Journal of Public Economics, 79(3), 455-483.

Tanzi, V. (1998). Corruption around the world: Causes, consequences, scope, and cures. Staff Papers, 45(4), 559-594.

Timmons, J. F., \& Garfias, F. (2015). Revealed corruption, taxation, and fiscal accountability: Evidence from Brazil. World Development, 70, 13-27.

Torgler, B. (2004). Moral suasion: An alternative tax policy strategy? Evidence from a controlled field experiment in Switzerland. Economics of Governance, 5(3), 235-253.

Torgler, B. (2013). A field experiment in moral suasion and tax compliance focusing on underdeclaration and overdeduction. FinanzArchiv: Public Finance Analysis, 69(4), 393411.

Traxler, C. (2010). Social norms and conditional cooperative taxpayers. European Journal of Political Economy, 26(1), 89-103. 
Tulkens, H., \& Jacquemin,A. (1971). The cost of delinquency: a problem of optimal allocation of private and public expenditure. Center for Operations Research \& Econometrics.

Uslaner, E. M. (2010). Tax evasion, corruption, and the social contract transition. In J. Alm, J. Martinez-Vazquez, J. and B. Torgler (Eds.), Tax compliance and tax evasion. Routledge. van Veldhuizen, R. (2011). Bribery and the Fair Salary Hypothesis in the Lab. Mimeo. University of Amsterdam

Vellutini, C., Casamatta, G., Bousquet, L. \& Poniatowski, G. (2019). Estimating International Tax Evasion by Individuals (Working Paper No. 76-2019. Taxation papers, European Commission. https:/ec.europa.eu/taxation_customs/sites/taxation/files/2019-taxationpapers-76.pdf

Yitzhaki S. (1974). A note on Income tax evasion: A theoretical analysis. Journal of Public Economics, 3(2), 201-202. 